\title{
PELATIHAN MOTIVASI KEWIRAUSAHAAN DAN MENGANALISIS PELUANG USAHA, MEMBUAT RENCANA BISNIS BAGI TENAGA KERJA WANITA (TKW) PURNA DI DESA CIBALONG KECAMATAN GUNUNG GURUH, SUKABUMI-JAWA BARAT
}

\author{
Dr. Corry Yohana, MM \\ Universitas Negeri Jakarta \\ corry_yohana@yahoo.com
}

\begin{abstract}
ABSTRAK
Tujuan dari pengabdian masyarakat ini adalah untuk Memberikan pelatihan dan memotivasi kepada individu tenaga kerja TKW purna dilingkungan desa Cibalong tentang pengetahuan praktis dan sederhana untuk menganalisis peluang usaha membuat Rencana Bisnis

Metode penelitian yang digunaka adalah metode klasikal dengan pendekatan diskusi/tanya jawab dan bisnis game (simulasi) dengan maksud agar materi dapat diterima oleh peserta dengan baik. Bimbinganlkonsultasi dilakukan baik melalui satu sesi pertemuan terakhir dengan peserta, telpon maupun melalui surat

Hasil pelatihan menunjukan dengan adanya pelatihan ini para peserta memiliki pengetahuan dan wawasan sebagai pengusaha kecil yang terampil mengelola keungan dan juga mampu mencari peluang untuk menambah keuangan keluarga sebagai bekal untuk meningkatkan taraf hidupnya agar menjadi lebih baik. Berdasarkan hasil pelatihan ini dapat disimpulkan peserta menginginkan pengetahuan yang berkelanjutan. Sangat diharapkan memberikan pengetahuan dalam bentuk pelatihan yang rutin dan berkesinabungan.
\end{abstract}

Kata Kunci: : Pelatihan, Peluang Usaha.Rencana Bisnis, Tenaga Kerja Wanita

\section{A. PENDAHULUAN}

Indonesia merupakan negara dengan penduduk yang sangat besar, menurut BPS tahun 2010 jumlah penduduk saat ini sebanyak jumlah penduduk Indonesia adalah 237.641.326 jiwa. Jika dihitung dengan asumsijumlah penduduk tersebut, meng• gunakan data pertumbuhan penduduk Indonesia yang dikeluarkan oleh bank dunia, yakni $1.21 \%$ per tahun, maka jumlah penduduk Indonesia tahun 2015 akan menjadi 252.370 .792 jiwa. Jumlah penduduk yang besar tersebut merupakan potensi pembangunan yang dapat memberi kontribusi positif bagi kemakmuran bangsa dan ncgara. Salah satu nilai positifnya adalah ketersediaan tenaga kerja yang melirnpah, walaupun data tahun 2014 menun jukan jumlah pengangguran sebanyak 7,39 jutajiwa $(6,25 \%)$. Hal ini dapat diartikan bahwa lapangan kerja dan berusaha sangat terbatas.

Pengangguran yang tinggi berdampak langsung maupun tidak langsung terhadap kemiskinan, krirni- nalitas dan rnasalah-masalah sosial politik yangjuga semakin meningkat. Dengan jumlah angkatan kerja yang cukup besar, arus rnigrasi yang terus mengalir, serta dampak krisis ekonomi yang berkepanjangan sampai saat ini, membuat permasalahan tenaga kerja menjadi sangat besar dan kompleks.

Memang masalah pengangguran telah menjadi momok yang begitu menakutkan khususnya di negara-negara berkembang seperti di Indonesia. Negara berkembang seringkali dihadapkan dengan besamya angka pengangguran karena sempitnya lapangan pekerjaan dan besarnya jumlah penduduk.

Menurut hasil laporan Badan Buruh Interna• sional dibawa naungan PBB, ILO (International Labour Organization), anka penganguran usia muda di ASEAN Indonesia menempati posisi tertinggi disusul oleh Filipina dan Malaysia (lihat tabel). Angka penganguran usia muda merupakan angka kerja usia produktif antara 15-24 tahun 

Tabet 1. Angka pengangguran Usia Muda di ASEAN, 2010-2013

\begin{tabular}{|l|c|c|c|c|}
\hline & \multicolumn{4}{|c|}{ Angka penganguran usia muda } \\
\hline & 2010 & 2011 & 2012 & 2013 \\
\hline A SEAN & 14,7 & 13,0 & 12,0 & 13,1 \\
\hline Brunei Darussalam & - & - & - & - \\
\hline Combodia & - & - & 3,8 & - \\
\hline Indonesia & 21,4 & 20,0 & 19,6 & 21,6 \\
\hline Lao PDR & 3,1 & - & - & - \\
\hline Malaysia & 11,4 & 10,0 & 10,3 & 10,4 \\
\hline Myanmar & - & - & - & - \\
\hline Philippines & 17,6 & 16,3 & 16,2 & 16,6 \\
\hline Singapore & 9,9 & 9,2 & 8,9 & 9,4 \\
\hline Thailand & 3,9 & 2,9 & 2,7 & 3,4 \\
\hline Vietnam & 7,0 & 5,2 & 5,5 & 6,2 \\
\hline
\end{tabular}

Sumber ILO 2015

Pada kondisi tersebut, maka sebagai penduduk usia produktif mencari altematif pekerjaan ke luar negeri, atau yang populer dinarnakan Tenaga Kerja Indonesia (TKI). Penempatan TKI ke luar negeri, merupakan salah satu upaya penanggulangan masalah pengangguran. Tahun 2014, TKI yang tercatat berada di Malaysia. sebanyak 1.250 .000 orang, di Arab Saudi 588.075 orang dan negara lain 32.073 orang. Harus diakui, meski jumlahnya terns turun, persoalan pengangguran masih jadi pekerjaan rumah pemerintah. Kepala Dinas Ketenagakerjaan Jawa Barat, Hening Widyatmoko mengakui, peluang bekerja di luar negeri sebagai TKI (Tenaga Kerja Indonesia) bisa menjadi solusi mengurangi pengangguran di Indonesia.

Dari data yang dipegangnya, Jawa Barat ter masuk daerah lumbung TKI. Per 2013 saja, ada 129.995 orang TKI yang berasal dari Jawa Barat. Tujuan keberangkatan paling favorit adalah Timur Tengah dan Asia Pasific. Kan tong TKI terbesar di Jawa Barat ada di Indramayu, disusul Cirebon, Cianjur dan Sukabumi.
Namun, dia tidak menampik bahwa solusi pengangguran dengan mengarahkan menjadi TKI bisa menimbulkan masalah baru. "Ini bukti bisa menjadi solusi walaupun akhimya menciptakan masalah bertubi-tubi," ucap Hening dalam diskusi di Kementerian Perindustrian,Jakarta, Rabu (30/4).

Masalah muncul mulai dari pra penempatan, penempatan hingga puma penempatan TKI. Menurut Hening, masalah TKI ada dari hulu hingga hilir, "80 persen itu masalah di tanah air. Ketika pemulangan saja masalah juga," tegasnya.

Belum lagi masalah penyiksaan yang menimpa pahlawan devisa ini. Se lama 2013 saja, ada 116 kasus penyiksaan yang menimpa TKI asal Jawa Barat. Kasusnya beragam hingga berujung meninggal dunia.

"Kasus daerah ini penempatan kiriman masa• lah di Arab Saudi 63 kasus, kemudian menyusul Kuwait dan Malaysia," tegasnya.

Kondisi ini tidak lepas dari faktor rendahnya kualitas TK.I asal Jawa Barat. Tingkat pendidikan didominäsi lulusan SD dan SMP mencapai 80 
persen. Lulusan SD saja mencapai 46,6 persen. Bahkan, menurut Hening, ada TKI asal Jawa Barat yang tidak bisa baca tulis.

Peran pemerintah dalarn pengelolaan TKI ini menitik beratkan pada aspek pembinaan, per• lindungan dan memberikan kemudahan-kemu• dahan kepada tenaga kerja tersebut dan perusahaan yang bergerak di jasa penempatan TK.I. Program penempatan tenaga kerja ke luar negeri memberi manfaat dalam mengatasi pengangguran, mening• katkan keterampilan dan kesejahteraan diri serta keluarga TKI, dan peningkatan penerimaan devisa. Perlindungan sosial merupakan aspek yang sangat krusial terhadap TK.I. Banyaknya kasus TKJ ber• masalah yang selalu muncul setiap tahun, mengin• dikasikan bahwa upaya perlindungan terhadap merek masih sangat minim. Data Badan Nasional Penempatan dan Perlindungan Tenaga Kerja Indonesia (BNP2TK.1) tahun 2014 menunjukkan sekitar 5-15\% dari 200-400 ribu orang TKI yang pulang ke Indonesia setiap tahunnya adalah TKI yang bermasalah. Masalah-masalah tersebut dian• taranya berkaitan dengan legalitas keberangkatan, menjadi korban tindak kekerasan/konflik dengan majikan berupa kekerasan fisik, penganiayaan seksual, masalah tidak digaji, dan sebagainya. Data TKI yang dipulangkan selama tahun 2014 dari Arab Saudi sebanyak 20.379 orang, sedangkan dari Malaysia sebanyak 26.428 orang

Efek dari hal tersebut, banyak TKI yang ber• masalah di luar negeri (TKI-B) dan juga WNI Overstayer (WNI-O) yang kemudian dipulangkan oleh pemerintah. Di samping itu, BNP2TKI juga menekankan pentingnya agar para TKI Puma men jadi produktif dengan modal yang didapatkannya saat bekerja sebagai TKI untuk kemudian dijadikan modal berwirausaha di daerahnya.

Dengan harapan mereka, baik para TKI-B, TKI Puma, dan WNI-O untuk bisa mandiri dan berwirausaha. menurut Rizal Saragih, bahwa melalui program pemberdayaan ini para TKI Puma, WNI Overstayers atau TKI-B yang telah dipulangkan diharapkan mampu hidup mandiri, sehingga mereka tidak akan bekerja kembali keluar negeri. "Intinya agar mereka bisa berwirausaha, jangan nganggur, tugas kami ini ya memotivasi dan memfasilitasi mereka lewat pelatihan ini," ujar Rizal, di Aula Multi Mas Tanjung Gading, Kabupaten Batubara,pada Selasa(29/09). Lebih lanjut Rizal menjelaskan bahwa mental kepribadian yang kuat ialah kuncinya, dengan memanfaatkan bekal pengalaman dan kegigihan mereka selama berjuang bekerja di luar negeri. Program Pelatihan yang diadakan ini tujuannya adalah untuk mengelola potensi, karakter dan kearifan lokal yang sudah ada di daerah masing-masing. peserta latih, agar nanti nya dapat menekuni usahanya dalam kelompok wirausaha masing-masing, sehingga tidak terpikir untuk kembali menjadi TKI. "Yang patut diingat adalah menjadi TKI bekerja ke luar negeri itu tidak untuk selamanya, melainkan sebagai pilihan ketika di tanah air belum ada kesempatan bekerja. Bagaimanapun juga bekerja dan berdedikasi di tanah air sendiri, tentunya lebih baik lagi.

\section{B. IDENTIFIKASI DAN PERUMUSAN MASALAH}

Berdasarkan uraian diatas, dapat diidentifikasi berbagai masalah sebagai berikut:

1. Tingkat penganguran yang tinggidi ASEAN

2. Banyak TKI yang bermasalah di luar negeri (TK.I-B)

3. WNI Overstayer (WNJ-O) yang kemudian dipulangkan oleh pemerintah.

4. Para mantan Tenaga Kerja Indonesia (eks TKI) agar dilakukan pendampingan dan mengadakan pelatihan wirausaha di kantong• kantong TKI.

5. Pelatihan kewirausahaan ini dibutuhkan para eks TKI yang baru pulang sehingga mereka mempunyai altematif pekerjaan yang lebih menguntungkan di dalam negeri daripada kembali ke luar negeri sebagai TKI

Berdasarkan identifikasi masalah diatas maka perumusan masalah dalam program pengabdian masyarakat ini adalah Bagaimana menganalisa peluang usaha, membuat rencana bisnis, motivasi dan semangat kewirausahaan bagi TKI puma di Sukabumi, Jawa Barat

\section{TUJUAN}

Tujuan dari dilakukannya kegiatan pengabdian ini adalah

1. Membekali TKI puma di Sukabumi, Jawa Barat

2. Membangun mindset para TKI Puma di Sukabumi untuk berwirausaha dan berani maju dan bersaing secara sehat 
3. Menganalisa peluang usaha, membuat rencana bisnis, motivasi dan semangat kewirausahaan

4. Agar memiliki pemahaman dan pengetahuan tentang pentingnya perencanaan dan penge• lolaan usaha yang tepat.

\section{MANFAAT}

Adapun manfaat program ini adalah:

l. untuk memberikan motivasi dan sekaligus membuka wawasan peserta latih hingga mampu mandiri.

2. Kepada para peserta latih diberikan pengeta huan tentang pengembangan ekonomi pro• duktif seperti, wirausaha, investasi, dan usaha• usaha produktif lainnya dengan memanfaat kan penghasilan selama menjadi TKI,

3. Mengembangkan potensi diri sendiri maupun lingkungan sekitarnya yakni sumber daya alam, dan lain-lain).

4. Selesai pelatihan para TKI purna dan keluarganya nantinya dapat memperoleh penghasilan secara terus-menerus hingga dapat meningkatkan ekonomi keluarganya serta masyarakat di sekitar domisilnya.

5. Memberikan pengetahuan tentang penyusunan Business plan

6. Sebagai forum untuk bertukar pengetahuan

\section{E. TNJAUAN PUSTAKA}

Wirausaha memang bukan hal yang mudah tetapi bukanjuga hal yang sulit. Kebenaran bermula saat kita mengetahui kesalahan. Jangan tak:ut gagal sebelum memulai. Keyakinan bulat memulai usaha akan lebih jika ada disertai dengan perencanaan usaha (business plan). Membuka usaha baru tidak mungkin tanpa ada rencana sebelurnnya. Rencana harus ada betapa pun sederhananya secara tertulis. Namun, wirausaha baru di Negara kita banyak yang tidak mau ataupun mungkin tidak mampu atau segan menulis rcncana tertulis tersebut karena berbagai alasan. Perencanaan yang tidak tertulis pasti sudah ada rekayasa dalam pikiran, yaitu suatu rekayasa secara sederhana tentang jawaban dari berbagai pertanyaan antara lain, usaha apa yang akan dibuka, mengapa memilih usaha tersebut, dimana lokasinya, siapa konsumennya, darimana sumber modal, dsb. Tampaknya wirausaha baru seperti ini cenderung melaksanakan kegiatan trial and error atau coba-coba. Seandainya gagal mereka akan beralih ke usaha yang lain. Model seperti ini banyak dijumpai dalam masyarakat bisnis kita.

Suatu rencana kerja yang dibuat tertulis dan resmi guna menjalankan perusahaan (business plan) merupakan perangkat tepat untuk memegang kendali perusahaan dan menjaga agar fokus usaha perusahaan tidak menyimpang. Pandangan di atas mungkin berlaku untuk Negara maju. Akan tetapi, para wirausaha baru di Negara kita kebanyakan menyimpan rencana perusahaan di dalam pikiran nya. Ini bukan berarti kita membenarkan model perencanaan di dalam pikiran saja. Minimal harus ada catatan-catatan tertentu secara tertulis yang akan diikuti dalam pelaksanaannya. Misalnya menyangkut orang atau personalia yang akan diberi tugas untuk menjalankan usaha, modal yang akan digunakan, dan sebagainya. Memulai suatu usaha baru tidak tepat kiranya jika langsung dalam bentuk usaha besar. Memang ada pengusaha yang langsung membuka usaha besar tanpa mempunyai pengalaman lebih dulu. Akibatnya jika usaha besar ini mengalarni benturan-benturan bisnis maka akan timbul kepanikan bagi pemiliknya sendiri dan perusahaan semacam ini gampang jatuh/mengalami kegagalan. Memulai wirausaha dalam bentuk usaha kecil akan memberikan pengalaman demi pengala• man dalam pengelolaan usahanya. Berdasarkan pengalaman setiap tahun dan data yang terkumpul dianalisis maka dengan mudah perusahaan ber• kembang menjadi perusahaan yang lebih besar. Untuk membangun jiwa kewirausahaan yang mampu membuat perencanaan bisnis (business plan) yang baik dan kemudian dia mampu mem• buat usaha yang layak dan menguntungkan atau dengan kata lain produktif dan profitable maka diperlukan adanya upaya nyata, misalnya pelatihan kewirausahaan. Pelatihan kewirausahaan yang dilaksanakan dalam rangka pengabdian kepada masyarakat ini diharapkan dapat menjadi motivasi bagi mahasiswa untuk menjadi seorang wira• usahawan.

Peluang usaha adalah suatu bidang kebutuhan pembeli dimana seorang wirausaha dapat mengelola usaha di bidang tersebut secara menguntungkan. Membaca peluang pasar merupakan hal yang esensial bagi seorang wirausahawan. Kelihaian mernbaca peluang pasar tidak hanya dilakukan untuk memulai suatu usaha, namun keahlian dalam membaca peluang usaha ini juga harus dirniliki 
saat ingin mengembangkan usaha, melakukan segmentasi pasar, maupun pada saat melakukan perluasan usaha. Namun seringkali, kemampuan membaca peluang pasar tidak pas sasaran, sehingga apa yang telah menjadi ekspektasi pada saat memulai usaha seringkali tidak tercapai. Hal-hal yang bisa dilakukan untuk menangkap peluang usaha sebagai berikut:

I. Melihat

2. Mendengar

3. Membaca

4. Menulis

Setelah melihat, mendengar, dan membaca, maka perlu untuk menuangkan semua analisis yang telah diambil yang akan menjadi tolok ukur atau pegangan dalam mengaplikasikannya.

Business plan merupakan salah satu sarana sistematis dalam mempertajam ide bisnis. Dengan bantuan business plan, ide-ide bisnis akan lebih terencana dan sistematis. Melalui pendekatan• pendekatan standar business plan, akan diketahui siapa saja pasar atau konsumen potensial, bagai mana proses pemasarannya, serta bagaimana proses operasional dari bisnis yang sedang dijalani. Pada perencanaan finansial, akan diketahui bagaimana pemasukan dan pengeluaran yang paling optimal. Dengan bantuan komputer, akan dapat disimulasikan posisi pos-pos keuangan yang dapat menghasilkan profit yang tinggi bagi bisnis. Selain itu, tentu saja akan diketahui juga pos-pos bisnis mana saja yang tidak memberikan keuntungan dan bahkan bisa menjadi beban bisnis.

Membuat business plan sangatlah penting bagi setiap pengusaha, tapi bila ini pertama kali mem • buatnya tentu kamu akan menemui beberapa kesulitan. Para pemilik bisnis akan beargumen tentang seberapa panjang business plan itu harus dibuat, namun biasanya satu halaman business plan bisa mengcover semua kebutuhan untuk memulai bisnis. Berikut adalah langkah mudah untuk menulis business plan:

1. Pembukaan

Pembukaan pada plan/rencana bisnis. Jelaskan siapa yang menulis, kapan dan untuk tujuan apa.

2. Rangkuman

Berikan kisi-kisi dari rencana/plan bisnis

Anda. Tuliskan bagian ini terakhir setelah semua bagian dibuat.

\section{Strategic Overview}

Tuliskan apa yang menjadi tujuan utama, dan kegiatan utama dari rencana bisnisnya. Apa tujuan jangka panjang, strategi kunci dan tujuan akhir

4. Status Saat lni

Rangkum apa yang sudah dicapai, performa keuangan, penjualan dan teknis sampai saat ini. Perkenalkan siapa saja yang terlibat dalam bisnis ini.

5. Penawaran Produk atau Jasa

Jelaskan secara singkat apa yang membuat produk Anda beda dengan yang lain. Apa yang membuatnya spesial?

6. Target Pasar

Tunjukkan siapa saja target pasar yang akan disasar. Berikan profil pelanggan, segrnen, trend danjuga kompetisi dibisnis ini.

7. Strategi Marketing dan Penjualan

Bagaimana Anda akan menjual produk ini? Bagaimana akan bersaing dengan pesaing dibidang yang sama? Berapa biaya marketing nya? dan sebagainya.

8. Teknologi

Berikan segala ha! yang berkaitan degan teknologi dan penelitian di usaha Anda.

9. Operasional

Bagaimana operasional akan di handel, bagaimana menjalankannya, berapa biaya dan sumber daya yang dibutuhkan.

10. Proyeksi Keuangan

Berikan tabel sederhana tentang proyeksi keuangannya.

11. Kebutuhan Pendanaan

Berapa tambahan pendanaan yang Anda butuhkan.

12. Implemetasi

Berikan timeline pengerjaan, dan aksi yang dibutuhkan agar rencana berjalan.

13. Kesimpulan

Berikan alasan mengapa bisnis ini akan

sukses, dan mengapa perlu didukung Format business plan tidaklah baku. Format business plan biasanya bergantung pada siapa yang akan membaca business plan. Mungkin ada pihak yang mengharuskan bagian exit strategy, mungkin ada juga yang menginginkan bagian tambahan seperti analisis regulasi. Penyusunan business plan sangat bergantung pada mengapa business 
plan dibuat dan siapa yang akan menggunakannya. Misalnya, business plan yang bersifat non-profit bisa saja fok:us membahas misi organisasi. Business plan dengan tujuan mendapatkan pendanaan bank mungkin lebih melihat seperti apa rencana keuangan bisnis, apakah dapat melunasi hutang, dan berapa lama waktu yang dibutuhkan untuk melunasi hutang. Jika business plan ditujukan untuk investor, isinya bisa saja lebih berfokus pada penawaran investasi, target pasar, dan exit strategy.

Business plan disusun dengan jangka waktu 3-5 tahun ke depan. Karena bertujuan untuk menjadi patokan perusahaan mencapai sasaran sekaligus mendapatkan pendanaan, business plan harus dilengkapi data yang dapat dipertanggungjawabkan kebenarannya. Data dapat berasal dari surnber ekstemal, atau internal. Sumber ekstemal mengacu pada data pihak luar yang relevan dengan usaha dan disediakan oleh pihak yang memiliki reputasi. Sementara sumber internal mengacu pada data hasil pengamatan yang kita lakukan.

Perencanaan usaha merupakan suatu dokumen yang menyatakan keyakinan akan kemampuan sebuah bisnis untuk menjual barang atau jasa dengan menghasilkan keuntungan yang memuaskan dan menarik bagi penyandang dana. Perencanaan usaha akan membuat kita dapat melihat dengan jelas apa• kah usaha yang dijalankan nanti memiliki prospek keberhasilan yang tinggi danjuga harus bisa menya• kinkan orang lain tidak akan merugi bila melaku• kan kerjasama. Perencanaan usaha juga harus didasarkan pada kebutuhan masyarakat akan adanya barang dan jasa yang ditawarkan oleh perusahaan tersebut, sehingga perencanaan usaha harus berbasis pada permintaan pasar.

Ada beberapa alasan penting mengapa pengelola usaha harus menyusun perencanaan usaha, antara lain

1. Untuk dipakai sebagai alat pengawasan dan pengendalian kegiatan usaha sehari-hari,

Perencanaan usaha yang telah disusun dengan baik akan memudahkan para pelaksana untuk mengetahui apakah tindakan mereka menyimpang atau sesuai dengan rencana.

Dengan adanya perencanaan usaha yang disusun (tentunya sebelurn suatu kegiatan dilaku• kan) dengan cermat dapatlah dipilih dan ditetapkan kegiatan-kegiatan mana yang diperlukan dan mana yang tidak
Dengan adanya perencanaan usaha, maka segala kegiatan dapat dilakukan secara tertib dan teratur sesuai dengan tahap-tahap yang semestinya.

2. Untuk mendapatkan pembiayaan dari Lembaga Pemberi Pinjaman ( $T$ o obtain the institution financing)

Dengan adanya perencanaan usaha yang jelas akan memudahkan kita untuk mencari bantuan kerjasama dari berbagai pihak karena didalam perencanaan usaha menunjukkan aspek keuangan, dan aspek pemasaran yang mana hat tersebut akan memudahkan pengelola usaha mendapat duk:ungan berupa pinjaman melalui lembaga pemberi pinjaman.

3. Untuk mendapatkan dana investasi ( $\boldsymbol{T}_{0}$ obtain investment finds)

Perencanaan usaha yang jelas juga memung• kinkan kita untuk mendapatkan pinjaman melalui pihak-pihak lain yang potensial yang akan men• duk:ung pemenuhan investasi usaha kita.

4. Untuk rnengatur dengan siapa harus bekerja sama ( $T_{0}$ arrange strategic alliances) Mengatur dan membentuk kerjasama dengan perusahaan• perusahaan lain yang sudah ada dan saling mengun• tungkan misalnya dari para produsen yang dapat diharapkan rnemasok barang buat perusahaan anda.

5. Untuk mendapatkan kontrak besar (To large contracts)

Perencanaan yang baik menarit minat perusahaan-perusahaan yang lebih besar memberi pekerjaan atau kontrak yang dapat dikerjakan oleh perusahaan anda

6. Untuk menarik tenaga kerja inti ( $T_{0}$ attract key employes)

Perencanaan yang baik mengundang orang• orang tertentu yang potensial atau mempunyai keahlian untuk bergabung bekerja sama dengan anda. Mungkin saja anda memerlukan orang-orang yang mempunyai kemampuan untuk menduduki posisi kunci dalam perusahaan anda namun anda harus berhati-hati menerima orang-orang tertentu yang dapat pula menjerumuskan perusahaan anda yang barn berdiri. 
7. Untuk memotivasi clan fokus ( $\boldsymbol{T}_{0}$ motivate and focus your management team) Perencanaaan yang baik menjamin adanya perhatian yang fokus pada tujuan dari berbagai personil yang ada dalam perusahaan. Sebab sebuah perusahaan akan ber* tumbuh makin lama makin komplek sehingga perencanaan usaha akan menjadi komponen yang sangat penting bagi setiap orang untuk tetap berpijak pada arah yang benar.

Sebuah perencanaan usaha paling tidak mem• punyai tiga tujuan utama yakni:

1. Sebagai Rencana Aksi (Action Plan)

Sebuah perencanaan usaha akan membantu untuk bergerak dan mengambil tindakan bisnis. Kita mungkin sudah lama memikirkan untuk memulai sebuah usaha, tetapi prosesnya mungkin tampak seperti sesuatu yang 'menakutkan' dan terlalu kompleks. Sebuah rencana usaha akan membantu untuk memilah-rnilah proses dimaksud menjadi bagian-bagian kecil yang lebih jelas. Dengan demikian sebuah masalah bisnis yang besar dapat dilihat sebagai sebuah urutan masalah masalah kecil. Dan dengan memecahkan masalah masalah kecil dimaksud, otomatis masalah besar tersebut juga akan dapat terpecahkan. Jadi menulis sebuah perencanaan usaha akan membantu dalam mengambil tindakan bisnis dengan membagi masalah besar ke dalam masalah-masalah kecil yang tidak terlalu rumit.

\section{Sebagai Peta Jalan (Road Map)}

Seketik:a memulai sebuah usaha, perencanaan usaha akan menjadi alat yang sangat berguna agar usaha tetap pada arah yang diinginkan. Dalam kegiatan bisnis schari-hari yang hiruk-pik:uk, sangat mudah bagi seseorang untuk kehilangan arah usaha untuk mencapai tujuan yang ingin dicapai. Sebuah rencana bisnis rnembantu untuk tetap fokus dalam arah yang diinginkan untuk mencapai tujuan yang telah dicanangkan. Juga perencanaan usaha akan membantu pihak lain untuk memahami visi usaha yang akan dijalankan, termasuk supplier, pekerja, mitra bisnis, teman dan keluarga.

\section{F. HASIL KEGIATAN}

Kegiatan Pelatihan Kewirausahaan dan Pem• buatan Busines Plan bagi TKW di Desa Cibalong Kecamatan Gunung Guruh, Sukabumi-Jawa Barat. dilaksanakan di kantor kepala desa. dengan nara sumber clan dibantu oleh tim panitia.
Peserta pelatihan seluruhnya 24 orang, terdiri dari Tenaga Kerja Wanita dari Saudi Arabiah. Pelaksanaan pelatihan tersebut berjalan lancar, hal ini dik:arenakan partisipasi dan keterkaitan semua pihak terutama masyarakat setempat yang sekaligus sebagai peserta.

Kegiatan ini dilaksanakan pada hari minggu, 21 Agustus 2016 pukul 08.30- 12.30 WIB. Pelatihan ini ditekankan pada keberhasilan peserta dalam menyerap materi khususnya melalui sesi Tanya jawab secara interaktif diantara para peserta juga narasumber. Selain itu diadakan sesi praktek oleh peserta secara berkelompok, diakhiri masukan dan arahan dari narasurnber. Selain sesi praktek peserta juga diberikan angket evaluasi pelaksanaan pela• tihan. Berdasarkan angket dapat dik:etahui sebagai berikut:

I. Peserta dapat mengetahui secara praktis dan sederhana mengenai Pembuatan Busines Plan sederhana

2. Peserta dapat memaharni dan mengerti ter hadap pengetahuan Pembuatan Busines Plan

3. Peserta termotivasi untuk pelatihan wirausaha dan Pembuatan Busines Plan.

\section{G. KESIMPULAN DAN SARAN \\ 1. KESIMPULAN}

Pelatihan memberik:an pengetahuan dasar ter• hadap Pembuatan Busines Plan bagi Tenaga Kerja Wanita (TKW). Dengan kegiatan ini diharapkan Tenaga Kerja Wanita (TKW) mendapatkan pema• haman dari materi yang diberikan juga dapat diaplikasik:an dalam kehidupan sehari-hari. Dengan adanya pelatihan ini diharapkan para peserta memiliki pengetahuan dan wawasan sebagai Tenaga Kerja Wanita (TKW) sebagai pengusaha kecil yang terampil mengelola Pembuatan Busines Plan dan juga mampu mencari peluang untuk menambah keuangan keluarga sebagai bekal untuk mcningkatkan taraf hidupnya agar menjadi lebih baik dan tidak ingin kembali sebagai Tenaga Kerja Wanita (TKW)

Evaluasi yang diberikan mcnunjukan peserta mcnginginkan pengetahuan yang berkelanjutan. Sangat diharapkan memberikan pengetahuan daJam bentuk pelatihan yang rutin dan berkesinabungan. 


\section{SARAN}

1. Peserta diharapkan dapat menerapkan Pem• buatan Busines Plan

2. Kegiatan ini memang harus dikembangkan sebagai wujud pengabdian kepada masyarakat dalam rangka peningkatan kualitas masyarakat pada umumnya dan pengusaha kecil pada khususnya.

3. Diharapkan kedepan jumlah dana yang dianggarkan untuk kegiatan pengabdian kepada Tenaga Kerja Wanita (TKW) bisa ditingkatkan jumlahnya

\section{DAFfAR PUSTAKA}

Finnansyah, T, "Pengangguran Terdidik Ber• tarnbah.", http://www.republika.eo.id/berita/koran/ halaman-1 / 14/11 /06/neltsa-pengangguran-terdidik• bertambah, diakses pada 15 Maret 2015.

Modul Seri Kewirausahaan Kementerian Koperasi dan UMKM Republik Indonesia.

Pedoman Program Mahasiswa Wirausaha (PMW) 2013, http://dikti.go.id/mahasiswa/bidang• minat-bakat-danatau-keorganisasian/program• mahasiswa-wirausaha-pmw/, diakses pada tanggal 27 Maret 2015.

Titik Purwinarti. 2012. Model Rencana Usaha Bagi Wirausaha Pemula Kecil dan Menengah.

Yildirirn, N., Askun, O. B., "Entrepreneurship Intentions of Public Universities in Turkey: Going Beyond Education and Research?" 8th International

Strategic Management Conference, Procedia Social and Behavioral Science, 2012

Untuk memotivasi dan fokus ( $\boldsymbol{T}_{0}$ motivate and.focus your management team) Perencanaaan yang baik menjamin adanya perhatian yang fokus pada tujuan dari berbagai personil yang ada dalam perusahaan. Sebab sebuah perusahaan akan bertumbuh makin lama makin komplek sehingga perencanaan usaha akan menjadi komponen yang sangat penting bagi setiap orang untuk tetap berpijak pada arah yang benar
Sebuah perencanaan usaha paling tidak mempunyai tiga tujuan utarna yakni:

1. Sebagai Rencana Aksi (Action Plan)

Sebuah perencanaan usaha akan membantu untuk bergerak dan mengambil tindakan bisnis. Kita mungkin sudah lama memikirkan untuk memulai sebuah usaha, tetapi prosesnya mungkin tampak seperti sesuatu yang 'menakutkan' dan terlalu kompleks. Sebuah rencana usaha akan membantu untuk memilah-milah proses dimaksud menjadi bagian-bagian kecil yang lebih jelas. Dengan demikian sebuah masalah bisnis yang besar dapat dilihat sebagai sebuah urutan masalahmasalah kecil. Dan dengan memecahkan masalah masalah kecil dimaksud, otomatis masalah besar tersebut juga akan dapat terpecahkan. Jadi menulis sebuah perencanaan usaha akan membantu dalam mengambil tindakan bisnis dengan membagi masalah besar ke dalam masalah-masalah kecil yang tidak terlalu rumit.

\section{Sebagai Peta Jalan (Road Map)}

Seketika memulai sebuah usaha, perencanaan usaha akan menjadi alat yang sangat berguna agar usaha tetap pada arah yang diinginkan. Dalam kegiatan bisnis sehari-hari yang hiruk-pikuk, sangat mudah bagi seseorang untuk kehilangan arah usaha untuk mencapai tujuan yang ingin dicapai. Sebuah rencana bisnis membantu untuk tetap fokus dalam arah yang diinginkan untuk mencapai tujuan yang telah dicanangkan. Juga perencanaan usaha akan membantu pihak lain untuk memaharni visi usaha yang akan dijalankan, termasuk supplier, pekerja, mitra bisnis, teman dan keluarga.

\section{Sebagai Alat Penjualan (SalesTool)}

Mungkin yang paling penting adalah bahwa sebuah perencanaan usaha merupakan sebuah alat bantu penjualan (Sales Tool), sehingga sebuah perencana• an usaha merupakan alat yang bisa diperguna kan untuk meyakinkan investor untuk menempat• kan investasinya di usaha tersebut.

Sebuah perencanaan usaha yang ditulis dengan baik akan mendekatkan pengelola usaha dengan pihak-pihak yang melihat bahwa ide bisnis yang ditawarkan akan juga menguntungkan mereka. 